\title{
Brachyury as a potential modulator of androgen receptor activity and a key player in therapy resistance in prostate cancer
}

\author{
Filipe Pinto ${ }^{1,2}$, Nelma Pértega-Gomes ${ }^{3}$, José R. Vizcaíno ${ }^{4}$, Raquel P. Andrade ${ }^{5,6}$, \\ Flavio M. Cárcano ${ }^{7,8}$ and Rui Manuel Reis ${ }^{1,2,8}$ \\ ${ }^{1}$ Life and Health Sciences Research Institute (ICVS), School of Health Sciences, University of Minho, Braga, Portugal \\ 2 ICVS/3B's - PT Government Associate Laboratory, Braga, Portugal \\ ${ }^{3}$ Department of Medical Oncology, Dana-Farber Cancer Institute, Harvard Medical School, Boston, Massachusetts, USA \\ ${ }^{4}$ Department of Pathology, Centro Hospitalar do Porto, Porto, Portugal \\ ${ }^{5}$ CBMR, Centre for Biomedical Research, Universidade do Algarve, Faro, Portugal \\ ${ }^{6}$ Regenerative Medicine Program, Department of Medicine and Biomedical Sciences, University of Algarve, Faro, Portugal \\ ${ }^{7}$ Clinical Oncology Department, Barretos Cancer Hospital, Barretos, S. Paulo, Brazil \\ ${ }^{8}$ Molecular Oncology Research Center, Barretos Cancer Hospital, Barretos, S. Paulo, Brazil \\ Correspondence to: Rui Manuel Reis, email: rreis@ecsaude.uminho.pt
}

Keywords: Brachyury, prostate cancer, therapy resistance

Received: September 21,2015 Accepted: March 14, $2016 \quad$ Published: March 31, 2016

\section{ABSTRACT}

Prostate cancer (PCa) is the most commonly diagnosed neoplasm and the second leading cause of cancer-related deaths in men. Acquisition of resistance to conventional therapy is a major problem for PCa patient management. Several mechanisms have been described to promote therapy resistance in $\mathrm{PCa}$, such as androgen receptor (AR) activation, epithelial-to-mesenchymal transition (EMT), acquisition of stem cell properties and neuroendocrine transdifferentiation (NEtD). Recently, we identified Brachyury as a new biomarker of PCa aggressiveness and poor prognosis. In the present study we aimed to assess the role of Brachyury in PCa therapy resistance. We showed that Brachyury overexpression in prostate cancer cells lines increased resistance to docetaxel and cabazitaxel drugs, whereas Brachyury abrogation induced decrease in therapy resistance. Through ChiP-qPCR assays we further demonstrated that Brachyury is a direct regulator of AR expression as well as of the biomarker AMACR and the mesenchymal markers Snail and Fibronectin. Furthermore, in vitro Brachyury was also able to increase EMT and stem properties. By in silico analysis, clinically human Brachyury-positive PCa samples were associated with biomarkers of PCa aggressiveness and therapy resistance, including PTEN loss, and expression of NEtD markers, ERG and BCl-2. Taken together, our results indicate that Brachyury contributes to tumor chemotherapy resistance, constituting an attractive target for advanced PCa patients.

\section{INTRODUCTION}

Prostate cancer $(\mathrm{PCa})$ is the most prevalent malignancy in men and the second leading cause of cancerrelated deaths [1]. Despite advances in prevention, early detection, surgical techniques and adjuvant radiotherapy/ chemotherapy, progression to advanced prostate cancer and metastasis is a frequent event that hinders patient's cure [2]. The fist-line therapy for PCa patients includes the blockade of androgen receptor (AR) activation and signaling based on androgen-deprivation therapy. This approach is effective at an early phase, but eventually tumors recur, leading to the known metastatic castrationresistant prostate cancer (mCRPC) with a lethal outcome [3]. The exact mechanisms underlying the development of mCRPC are not fully understood. It was proposed that it arises when cancer cells either maintain AR signaling in the absence of normal levels of ligand or no longer require activation of this pathway for survival and proliferation [11]. It has also been suggested an association between 
chemoresistance and epithelial-to-mesenchymal transition (EMT) in PCa, a mechanism by which cancer cells acquire a higher capacity to invade and further metastasize [13], as well as increased stem cell features (e.g. CD15 and CD133) [14, 15]. Moreover, androgen-deprivation therapy frequently induces the emergence of highly aggressive prostate phenotypes with neuroendocrine (NE) features [expression of chromogranin A ( $\mathrm{CHGA})$ and synaptophysin $(S Y P)]$, also called neuroendocrine transdifferentiation (NEtD) [16]. Thus, it is crucial to understand these mechanisms in order to identify therapeutic biomarkers and potential novel therapeutic approaches for these patients. Currently, docetaxel is one of the commonest therapeutic agent given as firstline chemotherapy for patients with mCRPC [4-6]. In the mCRPC patients with docetaxel-resistant phenotypes, it has been shown the survival benefit with second-line therapy using new drugs such as enzalutamide, abiraterone and cabazitaxel [7-10].

The T-box transcription factor Brachyury (T) plays a key role during early embryo gastrulation, a typical EMT process [22]. Lately, Brachyury has also been associated with tumor development and progression [17-21], and its role on EMT, stemness and cancer therapy resistance was described [23-29].

We recently reported Brachyury as a new and independent biomarker of poor prognosis in PCa patients $[21,30]$. We also demonstrated that Brachyury could be involved in EMT, stem and neuronal differentiation [21], an indicative of NEtD in PCa. In the present work we aimed to explore whether Brachyury is a molecular driver of the major mechanisms of prostate tumor therapyresistance, namely AR, EMT, NEtD and stemness, in prostate cancer cells treated with docetaxel and cabazitaxel.

\section{RESULTS}

\section{Brachyury promotes prostate cancer cell resistance to the chemotherapeutic agents docetaxel and cabazitaxel}

Comparing only the control cells (transfected with empty vectors), the metastatic PC3 cells (with endogenous Brachyury expression) demonstrated to be more resistant to docetaxel and cabazitaxel than the primary $\mathrm{PCa}$ 22RV1 and the bone metastatic DU145 cells (negative for Brachyury expression) (Supplementary Figure S1B). To explore the hypothesis that Brachyury could influence therapy response, we used the primary PCa 22RV1 and the brain metastatic PCa DU145 cell lines (both Brachyury-negative) previously modulated to overexpress Brachyury (pcBrachyury) and the bone metastatic PC3 cell line (Brachyury-positive) with Brachyury sh-mediated depletion (sh.Brachyury) (Supplementary Figure S1A) [21]. Cells were treated with different concentrations of docetaxel or cabazitaxel to determine the $\mathrm{IC}_{50}$ of each cell line (22RV1 and DU145 4T/0 vs pcBrachyury; PC3 pLKO.1 vs sh.Brachyury). All cell lines used are androgen-independent to better explore the implication of Brachyury in castrate resistance prostate cancer (CRPC) therapy. The overexpression of Brachyury in 22RV1 cells was significantly associated with a higher resistance to both cytotoxic drugs [(docetaxel: $4 / \mathrm{T} 0 \mathrm{IC}_{50}=0.17 \pm 0.04 \mathrm{nM}$, pcBrachyury $\mathrm{IC}_{50}=1.54 \pm 0.07 \mathrm{nM} ; \mathrm{p}<0.001$ ), Figure 1A; (cabazitaxel: $4 / \mathrm{T} 0 \quad \mathrm{IC}_{50}=1.95 \pm 0.06 \mathrm{nM}$, pcBrachyury $\left.\mathrm{IC}_{50}=28.85 \pm 1.12 \mathrm{nM} ; \mathrm{p}<0.001\right)$; Figure 1B]. Similar results were also obtained in the metastatic DU145 cell line with Brachyury overexpression (Supplementary Figure S1C). When Brachyury was depleted on PC3 cells we observed a significant decrease in the $\mathrm{IC}_{50}$ for both drugs used, compared with control cells [(docetaxel: pLKO.1 $\mathrm{IC}_{50}=1.57 \pm 0.04 \mathrm{nM}$, sh.Brachyury $\mathrm{IC}_{50}=0.96 \pm 0.03 \mathrm{nM}$; $\mathrm{p}<0.01$ ), Figure 1C; (cabazitaxel: $\mathrm{pLKO} .1$ $\mathrm{IC}_{50}=13.37 \pm 0.58 \mathrm{nM}$, sh.Brachyury $\mathrm{IC}_{50}=1.09 \pm 0.41 \mathrm{nM}$ $; \mathrm{p}<0.05$ ), Figure 1D]. Altogether, these results indicate that the presence of Brachyury in PCa cells is directly associated with resistance to current chemotherapymediated treatments used in CRPC therapy.

\section{Presence of Brachyury in PCa correlates with resistance plasticity mechanisms EMT and stemness}

We have previously shown by in silico analysis in PCa samples that Brachyury is associated with altered expression of genes involved in epithelial-to-mesenchymal transition (EMT), namely $E$ and $N$-cadherin, Snail, $T G F-\beta 1$, fibronectin, MMP14 and MMP24, and in stemness (CD44) [21]. To corroborate our previous results, we performed RT-qPCR in a primary PCa cell line (22RV1) with modulated Brachyury expression (Supplementary Figure S2A). We found that Brachyury overexpression was significantly associated with the decrease of the epithelial marker E-cadherin and an increased expression of the mesenchymal marker Snail (Supplementary Figure S2A).

We further evaluated the involvement of Brachyury in gain of stemness properties in PCa cells. We found that Brachyury is able to increase the number of prostatespheres and the self-renewal capacity over time in 22RV1 cells Brachyury-positive cells (pcBrachyury) compared with Brachyury-negative cells (4/T0) (Figure 2A) (Figure 2A). Moreover, Brachyury was able to significantly increase the expression of the stem markers CD44 and CD15 (Figure 2B). Interestingly, we observed that 22RV1 $\mathrm{PCa}$ cells under sphere-forming conditions showed an increase of Brachyury expression, when compared with cells cultured in basal/monolayer conditions, with 
statistical significance in endogenous negative cells (4/T0) (Figure 2C). The influence of Brachyury in stemness was also addressed in metastatic DU145 cell line with ectopic Brachyury expression and in PC3 cell line with Brachyury depletion. Although we have found an increased number of aggregates in Brachyury-positive cells, they not form spheres (Supplementary Figure S2B).

Together, Brachyury overexpression occurring in PCa tissues could contribute to tumor cell plasticity mechanisms as EMT and gain of stem cell properties. Moreover, we showed that prostate tumor cells could upregulate Brachyury under stemness conditions.

A

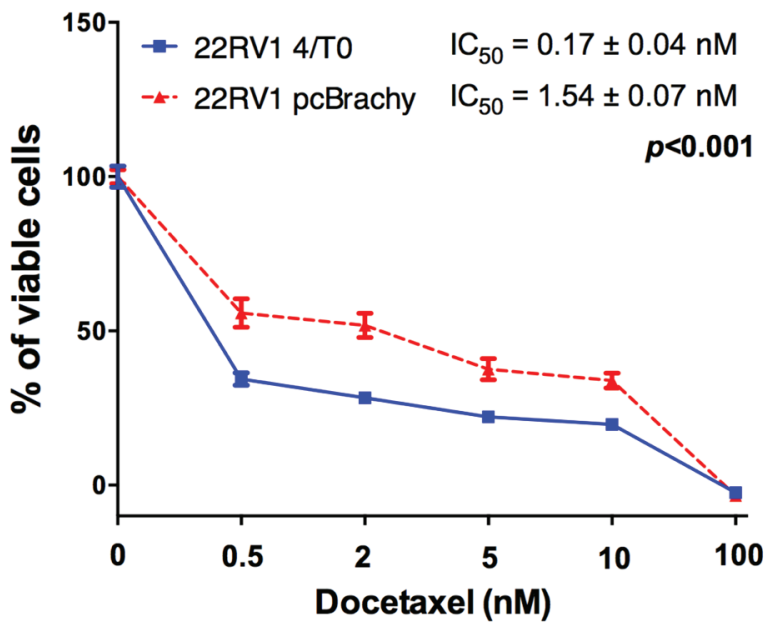

C

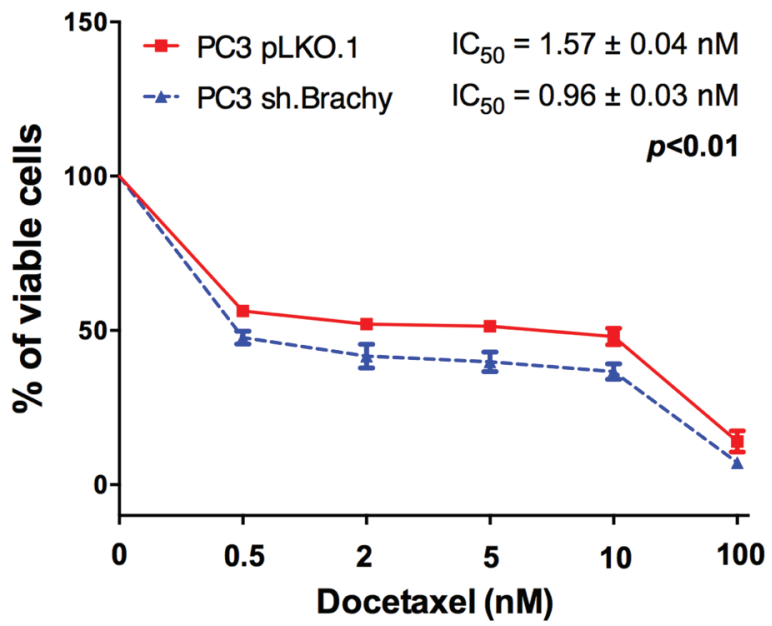

Brachyury is co-expressed with AR, ERG, Bcl2, NEtD markers and inversely with PTEN in human PCa tissues

To assess whether Brachyury is related with AR expression, we analyzed 155 normal prostate tissues and 311 primary $\mathrm{PCa}$ tissues by immunohistochemistry (Figure $3 \mathrm{~A}$ and 3B), previously characterized for Brachyury expression [21]. We found that presence of Brachyury protein in the nucleus of primary PCa tissues is statistically associated with the presence of AR ( $p=0.017$; Figure $3 B$ ), a feature not observed in normal prostate tissues $(p=0.362$; Figure 3B). Moreover, western blot analyses of PCa cell lines with Brachyury modulation showed that Brachyury

B

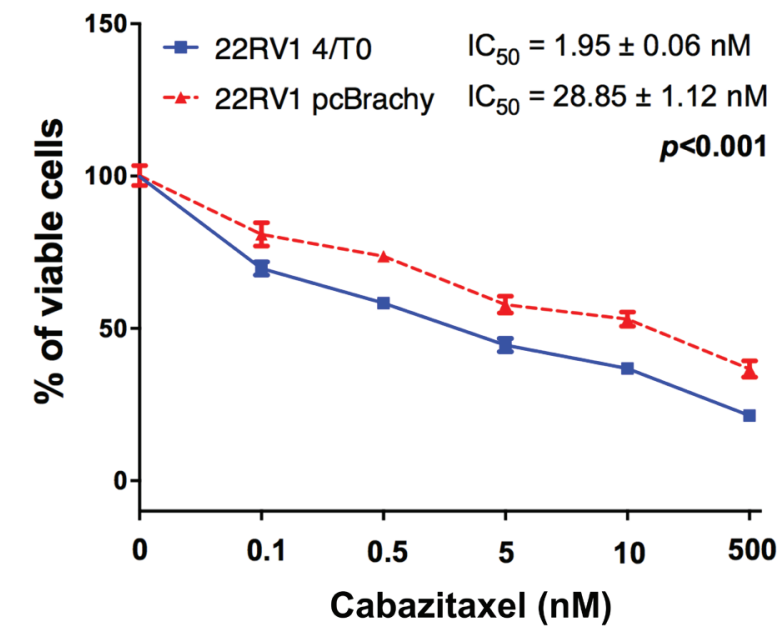

D

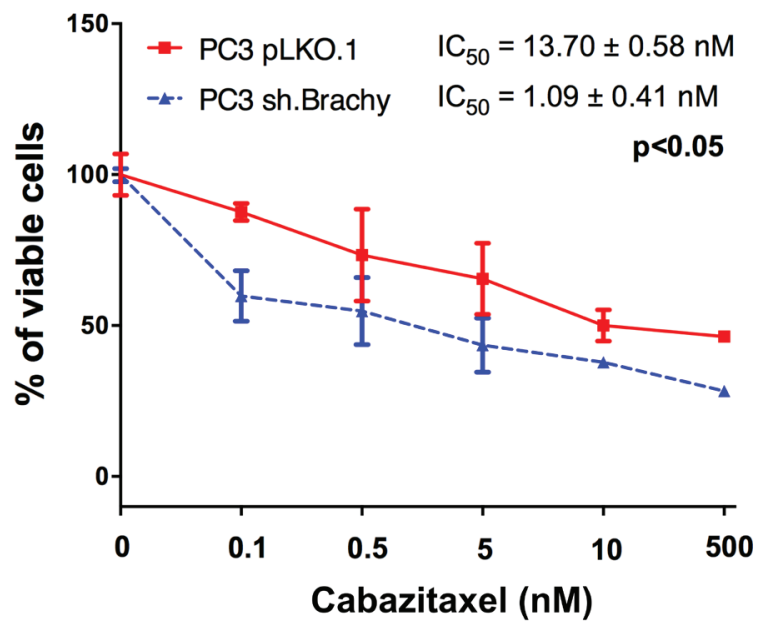

Figure 1: Brachyury promotes resistance to the cytotoxic drugs docetaxel and cabazitaxel. Brachyury overexpression increases significantly the $\mathrm{IC}_{50}$ of $22 \mathrm{RV} 1$ cells for both $\mathbf{A}$. docetaxel and $\mathbf{B}$. cabazitaxel. Brachyury depletion on PC 3 cells decreases the $\mathrm{IC}_{50}$ for $\mathbf{C}$. docetaxel and $\mathbf{D}$. cabazitaxel. Data for drug assays are mean \pm S.E.M, of 3 biological independent experiments with 3 technical replicates each. 
overexpression significantly increases AR expression and when Brachyury is depleted there is a concomitant decrease of AR expression (Figure 3C, D, E, F). We also observed that docetaxel treatment is able to decrease AR expression in 22RV1 cells in absence of Brachyury (4/T0 22RV1, $\mathrm{p}<0.05$ ), but not in the Brachyury-overexpressing cells. No effect was observed in PC3 cell line, indicating that effect of docetaxel in AR downregulation is cell-type dependent (Figure 3C, D, E, F). Based on these results, we may hypothesize that increased AR expression promoted by Brachyury can lead to docetaxel and cabazitaxel resistance (Figure 1).
The correlation between Brachyury and AR was also corroborated by in silico analysis in a series of 28 non-tumoral and 94 PCa samples (Figure 3G). We found that expression of the $A R$ was significantly increased in $\mathrm{PCa}$ tissues as compared to the normal prostate gland and is co-expressed with Brachyury ( $T$ ) (Figure 3A). We extended our in silico analysis to other genes described to be associated with poor patient prognosis and with PCa progression to a castration-resistant phenotype [31, 32]. Brachyury co-expression was correlated with PTEN (the most frequently downregulated tumor-suppressor gene in PCa), Bcl-2 (associated with therapy resistance) and $E R G$
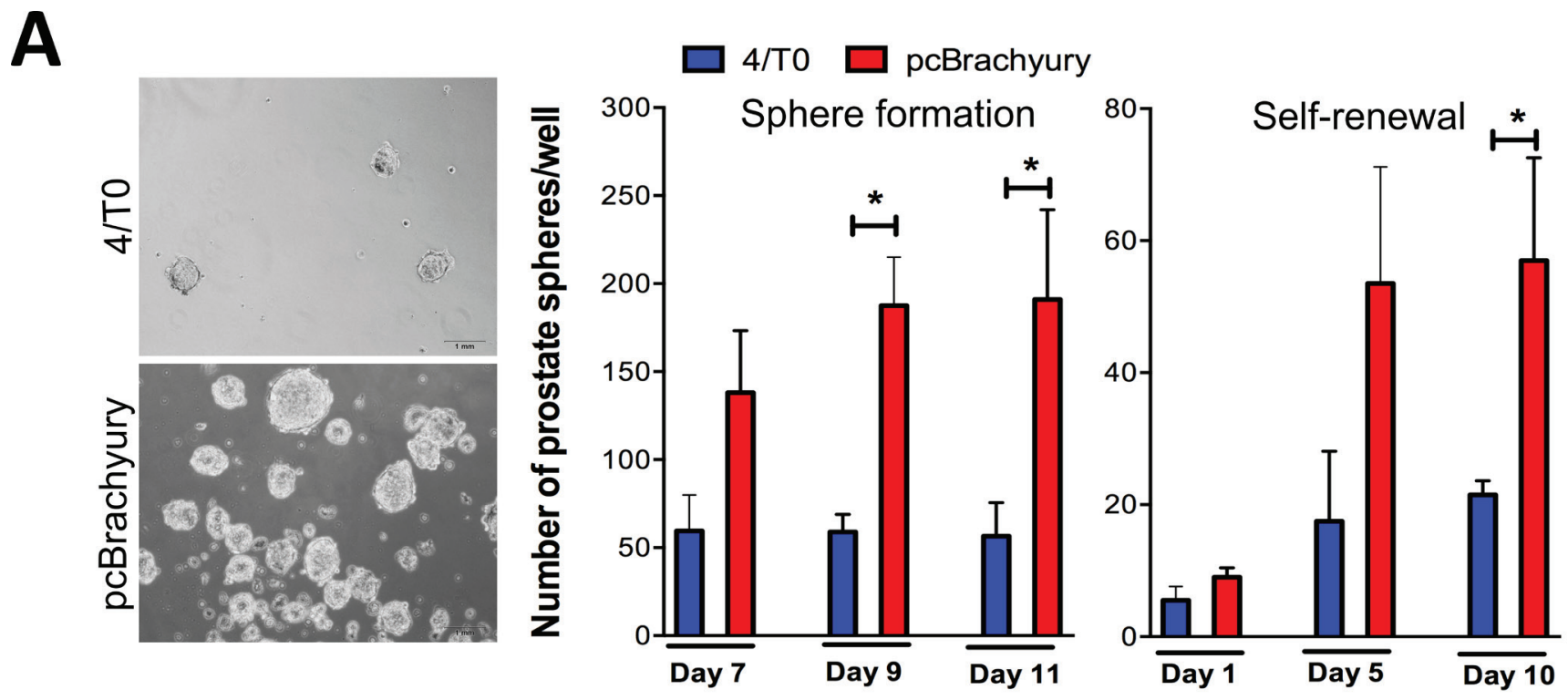

B
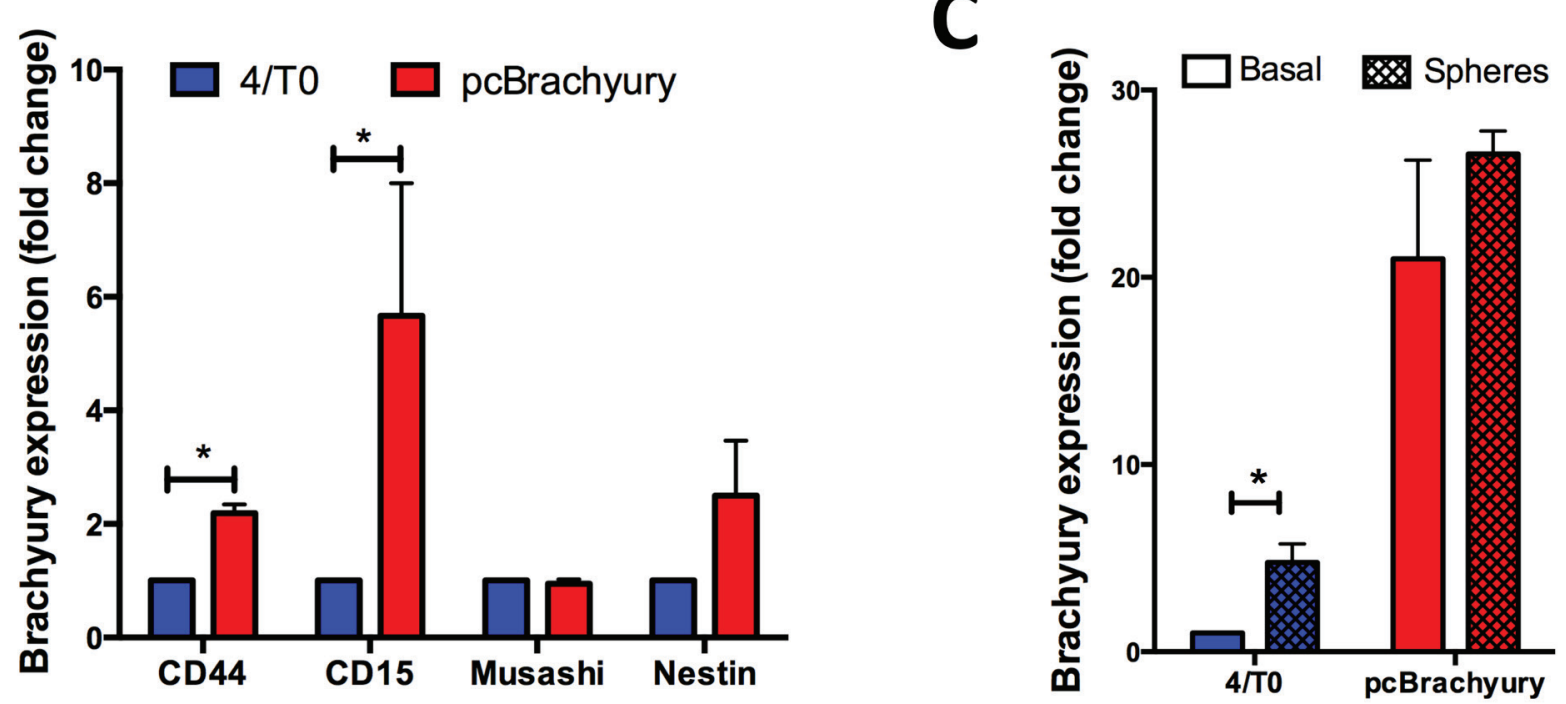

Figure 2: Brachyury promotes stem cell properties in PCa cells and is re-expressed under pressure conditions. A. In 22RV1 cells Brachyury is able to enhance the capacity to form prostate-spheres and self-renewal over time, as well as B. increases the expression of stem cell markers $C D 44$ and $C D 15$. C. Brachyury is up-regulated in negative 22RV1 cells when cultured under stem cell medium. Results of prostate-sphere are representative of two biological independent experiments in duplicate. Graphs of expression are mean \pm S.E.M of 3 biological independent experiments with 3 technical replicates each. ${ }^{*}, p<0.05$. 
(overexpressed due TMPRSS2-ERG fusion). As shown in Figure 3G, a strong association was found between Brachyury expression and Bcl-2 and ERG expression and PTEN loss (Figure 3G).

We previously showed that genes co-expressed with Brachyury are clustered in processes of neuron differentiation and central nervous system development [21]. This finding is indicative that Brachyury could be involved in the NEtD process. To better understand this mechanism we investigated the co-expression
A

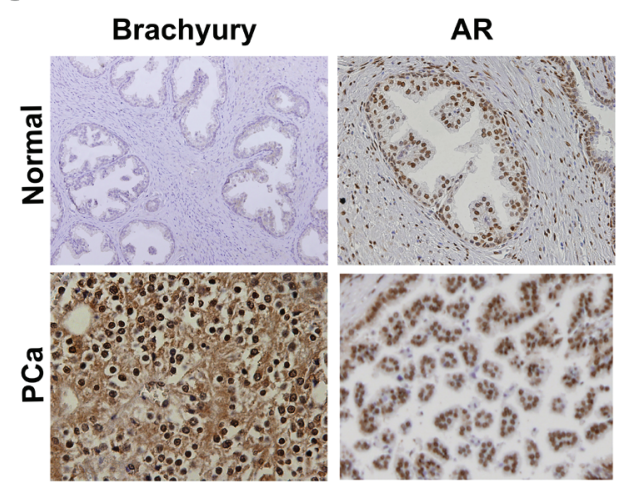

B

\begin{tabular}{c|c|cc|c}
\multirow{2}{*}{ Molecular features } & \multicolumn{4}{|c}{ Brachyury nuclear expression } \\
\cline { 2 - 5 } & $\mathrm{N}$ & Negative (\%) & Positive (\%) & $p$ value \\
\hline AR normal adjacent & & & & \\
Negative & 109 & 86.2 & 13.8 & 0.362 \\
Positive & 46 & 82.6 & 17.4 & \\
AR PCa tissue & & & & \\
Negative & 107 & 87.9 & 12.1 & $\mathbf{0 . 0 1 7}$ \\
Positive & 204 & 77.5 & 22.5 &
\end{tabular}

C
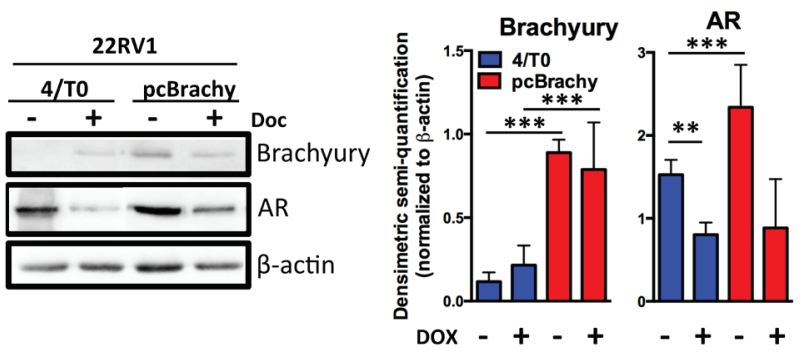

D

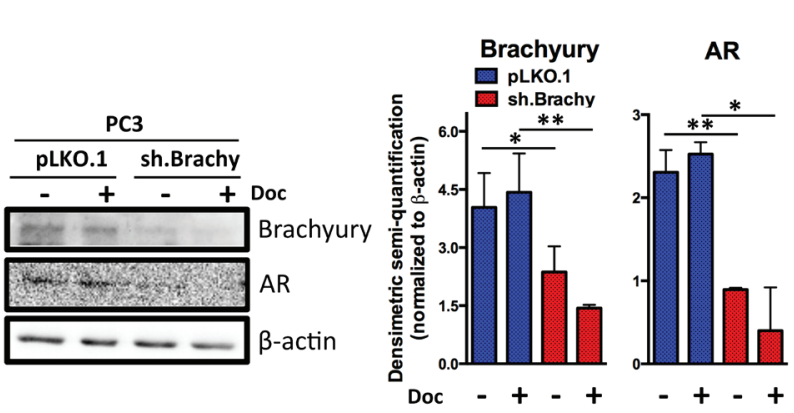

E
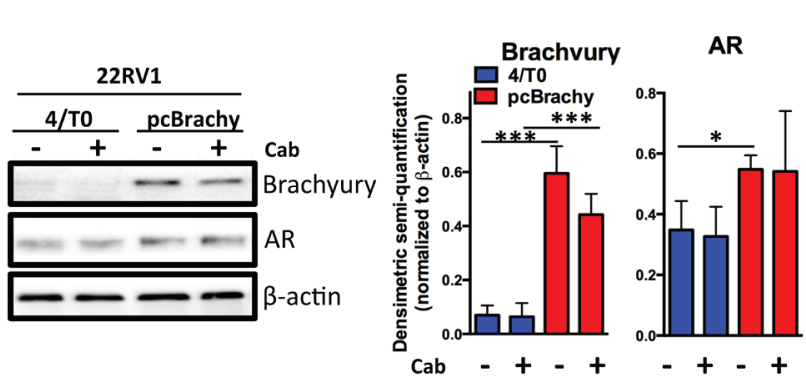

$\mathbf{F}$
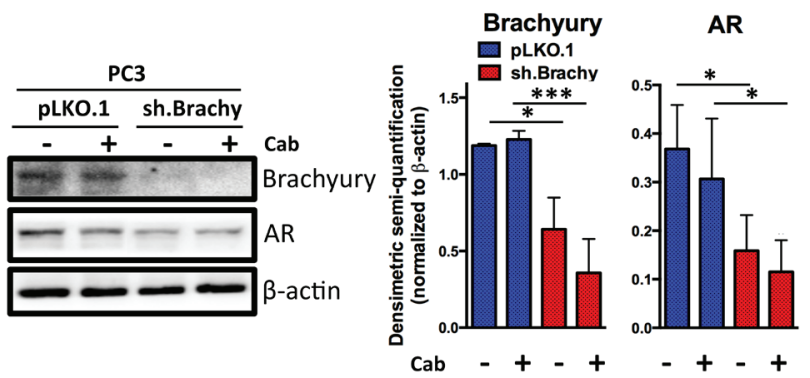

G

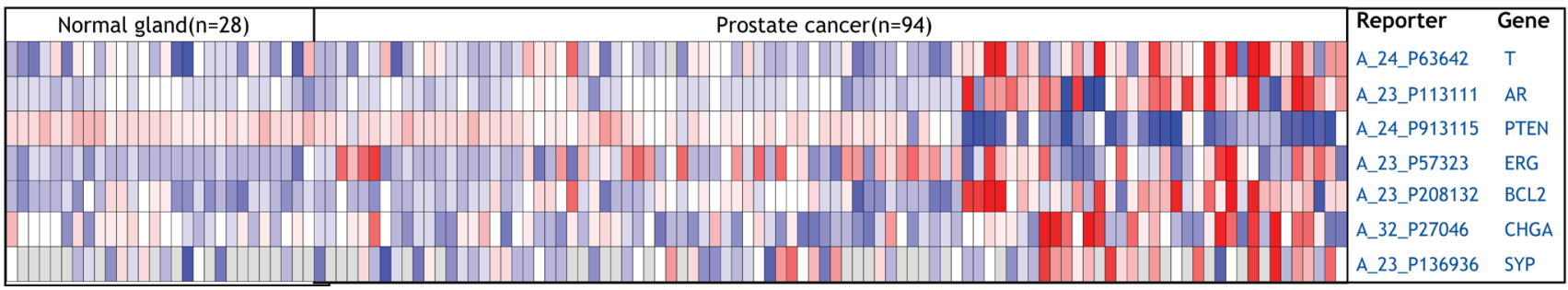

Figure 3: Brachyury is associated with AR, Bcl-2, ERG, CHGA and SYP expression and with loss of PTEN expression. A. Representative images of Brachyury and AR staining in normal and primary PCa tissues. B. Correlation of Brachyury and AR staining in prostate tissues. Nuclear Brachyury staining is correlated with AR only in primary PCa tissues. C.-F. Western blot analyses for Brachyury and AR expression in prostate cell lines treated with docetaxel (Doc) or with cabazitaxel (Cab). Graphs represent the densimetric semiquantification of western blot images. G. Heatmap showing the co-expression of Brachyruy (T), AR, PTEN, Bcl-2, ERG, CHGA and SYP in normal and PCa human samples from Oncomine database. 
of Brachyury with chromogranin $A(C H G A)$ and synaptophysin (SYP) in silico, two NEtD markers described to distinguish prostate tumors with NE features. We found that Brachyury is strongly correlated with NEtD markers, reinforcing its involvement in NEtD (Figure 3G). A gene signature that includes expression of Brachyury, CHGA, SYP, AR and loss of PTEN was found (Figure $3 \mathrm{G})$, being correlated with more aggressive tumors. The direct involvement of Brachyury in CHGA, SYP, AR, Bcl2, $E R G$ and PTEN expression is still unclear; however, the association with these well-established markers of PCa progression supports the importance of Brachyury as a new biomarker of PCa aggressiveness.

\section{Brachyury directly binds to the promoters of Snail and Fibronectin (mesenchymal biomarkers), AMACR (PCa biomarker) and AR}

A correlation between the expression of Brachyury with CD44, $N$-cadherin, Snail, fibronectin, AMACR and AR (present study and [21]) in PCa cells suggested that Brachyury could directly regulate these genes. To validate this hypothesis, we performed ChIP-qPCR in PC3 cell line with endogenous Brachyury expression. Analyses of $6 \mathrm{Kbs}(-5 \mathrm{~Kb}$ to $+1 \mathrm{~Kb})$ of the CD44, N-cadherin, Snail, Fibronectin, AMACR and $A R$ promoter regions revealed presence of T-Box binding sites in all genes (Figure 4A,
T-Boxs represented in red). However, a higher number T-Box binding site clusters was only found on $A R$ (26 T-Boxs), AMACR (25 T-Boxs), Snail (11 T-Boxs) and Fibronectin (9 T-Boxs) in opposite with CD44 and $N$-cadherin that only present 2 and 3 T-Box sites, respectively (Figure 4A).

The cross-linked DNA-protein complexes were immunoprecipitated with anti-Brachyury or with control IgG antibody. PCR amplification was performed using primers flanking regions with T-Boxs (blue arrows, Figure 4A). The results of ChIP-qPCR analysis showed that upstream regions of the mesenchymal marker genes Snail and Fibronectin, the PCa biomarker $A M A C R$ and $A R$ precipitated with anti-Brachyury antibody showing that Brachyury directly binds to regulatory elements of these genes and suggests possibly regulation of those genes (Figure 4B).

\section{DISCUSSION}

In the present study we provided the first evidences that Brachyury regulates several biological mechanisms associated with of PCa therapy resistance. Importantly, we showed that Brachyury directly regulates AR expression and promotes chemoresistance in PCa cells. Moreover, we also showed that Brachyury might also be a direct regulator of AMACR biomarker, in agreement with

\section{B}
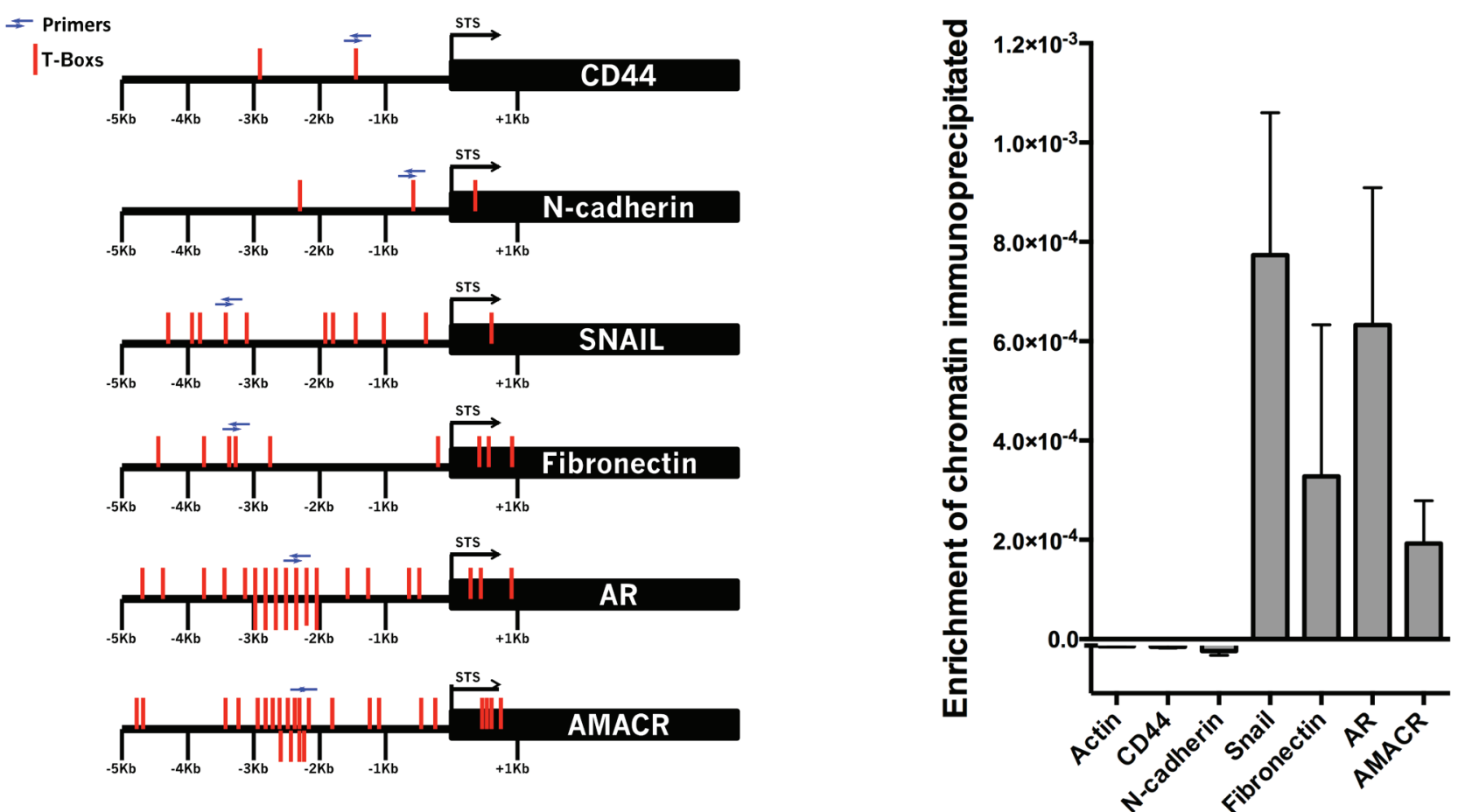

Figure 4: Brachyury directly binds to the promoter regions of Snail, Fibronectin, AMACR and AR. A. Squematic representation of the T-Boxs (red) in the region analyzed (6Kbs) and the localization of the primers (blue arrows) used in the ChIP-qPCR. B. Brachyury showed an enrichment of chromatin immunoprecipitated for Snail, Fibronectin, AMACR and AR, but not for the negative control $\beta$-actin, $C D 44$ and $N$-cadherin. The graph represents mean \pm S.E.M. of three biological experiments with 3 technical replicates. 
our previously results [21]. These results indicate that Brachyury alone or in combination with AMACR, could be used in routine setting as a PCa diagnosis biomarker.

Using ChiP-qPCR we were able to show that Brachyury is a direct regulator of AR. This finding was further validated by immunohistochemistry of a cohort of PCa patients and in silico analysis. We found a particular association when Brachyury is present only in the nucleus, not in the cytosol. We believe that correlation of Brachyury and AR in the nucleus could be a direct consequence of Brachyury role in activation $A R$ expression and consequently therapy resistance. Moreover, Brachyury presence in the cytosol could be a surrogate marker of PCa aggressiveness. By ChiP-qPCR, we also observed that Snail and Fibronectin - typical mesenchymal markers - are directly regulated by Brachyury, strongly suggesting its role in the EMT process. These results are in agreement with our previous study, where we showed that Brachyury increases migration and invasion capabilities in PCa cells and it was correlated with EMT markers (fibronectin, MMP14, MMP24, Snail, IL8 and $T G F-\beta 1$ ) by in silico analysis [21]. Moreover, Brachyury overexpression increases expression of stem cell markers (CD44, CD15 and Nestin) being associated with increased capacity of PCa cells to form prostate-spheres and with self-renewal in 22RV1 cell line. The absence of effect on stem in the other PCa cell lines suggests that Brachyury is not the only mechanism responsible for increased stem cell capabilities, but probably it involve more complex mechanisms, once the genetic background of each cell line could influence it. Furthermore, Brachyury was also associated with NE markers ( $C H G A$ and $S Y P)$, reinforcing the hypothesis that it is involved in the NEtD process and consequently higher aggressive tumors. Brachyury was previously associated with the NE marker CHGA, in colorectal cancer, distinguishing a specific subpopulation of stem cells [33].

The involvement of Brachyury in tumor resistance, namely to docetaxel, was previously described in breast cancer [27, 28]. In accordance, we demonstrated that Brachyury promotes higher resistance not only to docetaxel, but also to cabazitaxel, two currently chemotherapeutic agents used in CRPC treatment. A recent genome-wide analysis on $A R$ that showed an enrichment of T-Box motifs in LAPC-4 prostate cells after chemotherapy [34], indicating that Brachyury is involved in $A R$ expression during PCa therapy and consequently increased therapy resistance. We hypothesize that this effect on Brachyury expression can be extrapolated to other pressure conditions, as longer periods exposed to chemotherapy. Interestingly, we found that Brachyury can be re-expressed under pressure conditions, as can happen during chemotherapy of PCa. Indeed, lung cancer cells exposed to successive cycles of chemotherapy (docetaxel) selection and recovery showed elevated Brachyury expression levels compared with untreated cells [18].
Several molecular events, such as TMPRSS2-ERG fusion, $\mathrm{Bcl}-2$ overexpression, as well as PTEN loss has been described as major biomarkers of PCa aggressiveness and therapy response [35-38]. Herein, we showed that Brachyury is co-expressed with the ETS transcription factor $E R G, B c l-2$ and inversely co-expressed with PTEN. In hepatocellular carcinoma cells, Brachyury showed to increase Akt signaling activation by inhibition of PTEN expression [39]. This recent finding together with the present data, suggest that in PCa Brachyury can suppress PTEN leading to increased activation of Akt signaling and consequently aberrant transcription of downstream checkpoint genes, like $B c l-2$ and $E R G$. Aberrant expression of an ETS transcription factor (usually ERG) is also found in response to the activated AR [38], as those promoted by Brachyury overexpression. This signaling crosstalk could provide the selective advantage at the cellular level to allow PCa progress and be resistant to current therapy. Therefore, Brachyury can constitute an attractive therapeutic target.

Recently a Phase II clinical trial was initiated with the yeast-Brachyury vaccine GI-6301 (www.clinicaltrials. gov, NCT02383498, 2015) to treat patients with advanced carcinomas. Preliminary results showed that Brachyury vaccine was well tolerated and Brachyury-specific $\mathrm{CD} 8+$ and/or CD4+ T-cell responses were present in the blood of some patients post- versus pre-vaccination [40, 41]. This evidence together with results obtained in the present study indicates that Brachyury could be used as an immunotherapeutic target in patients with advanced PCa.

In conclusion, we have demonstrated the importance of Brachyury in $\mathrm{PCa}$ resistance to chemotherapeutic agents by modulating several tumorigenic and aggressive mechanisms. Additionally the previous association of Brachyury with PCa patient prognosis [21] and current therapy response suggest that Brachyury could be a important theranostic biomarker for advanced prostate cancer patients.

\section{MATERIALS AND METHODS}

\section{Brachyury and androgen receptor (AR) correlation in human prostate tissues}

$\mathrm{AR}$ and Brachyury co-expression was assessed in a cohort of 155 normal prostate tissues and 311 primary $\mathrm{PCa}$ tissues, where we previously described the expression and distribution of Brachyury [21].

For AR staining histological slides with $4 \mu \mathrm{m}$-thick tissue sections were subjected to immunohistochemistry analysis according to the streptavidin-biotin peroxidase complex system (UltraVision Large Volume Detection System Anti-Polyvalent, HRP; LabVision Corporation), using the primary antibody raised against AR (diluted 
1:750; sc-816, Santa Cruz Biotechnology, Inc). AR immunohistochemistry results were semi-quantitatively scored. Tumors were graded as negative when expression was seen in less than $5 \%$ of nuclei, 1 when staining $5 \%$ to $10 \%$ of nuclei, 2 when staining more than $10 \%$ to $50 \%$ of nuclei, and 3 when staining more than $50 \%$ of nuclei. Samples with scores 0,1 were considered negative and those with scores 2 and 3 were considered positive.

\section{Cell lines and cell culture conditions}

Human prostate cell lines 22RV1, DU145 and PC3 (ATCC-American Type Culture Collection, MD, USA) were grown in Roswell Park Memorial Institute medium (RPMI)-1640 (GIBCO ${ }^{\circledR}$, Invitrogen) cell culture medium supplemented with 10\% Fetal Bovine Serum (FBS) (GIBCO ${ }^{\circledR}$, Invitrogen) and $1 \%$ Penicillin-Streptomycin $(\mathrm{P} / \mathrm{S})(\mathrm{GIBCO} \otimes$, Invitrogen).

\section{Brachyury over-expression and silencing in PCa cells}

22RV1 and DU145 were transfected with fulllength human Brachyury cDNA in pcDNA4/T0 vector (designed as pcBrachyury) or with empty vector (4/T0). For Brachyury silencing, PC3 cells were transfected with pLKO.1 plasmid containing Brachyury-specific shRNA (sh.Brachyury) or empty vector alone (pLKO.1) [21]. Transfected 22RV1 and DU145 cells were maintained under selection with Zeocin $50 \mu \mathrm{g} / \mathrm{ml}$ (Invitrogen). Stable PC3 cells with depleted endogenous Brachyury expression were maintained with $5 \mu \mathrm{g} / \mathrm{ml}$ of puromycin (Sigma Aldrich), as previously described [21].

\section{Western blot analysis}

Cells were lysed in $50 \mathrm{mM}$ Tris $\mathrm{pH} 7.6-8,150$ $\mathrm{mM} \mathrm{NaCl}, 5 \mathrm{mM}$ EDTA, $1 \mathrm{mM} \mathrm{Na} \mathrm{VO}_{4}, 10 \mathrm{mM} \mathrm{NaF}$, $10 \mathrm{mM}$ NaPyrophosphate, $1 \% \mathrm{NP}-40$ and $1 / 7$ of protease cocktail inhibitors (Roche). Proteins were resolved on standard $12 \%$ SDS-PAGE gel and transferred onto nitrocellulose membranes. The immunodetection was achieved using antibodies for human Brachyury (AF2085, R\&D Systems), AR (ab108341, Abcam) and $\beta$-actin (sc-1616, Santa Cruz Biotechnology). Detection was done by chemiluminescence (SuperSignal West Femto Chemiluminescent Substrate; Thermo Scientific). Protein expression quantification was performed by ImageJ software (version 1.44).

\section{RNA extraction and reverse-transcriptase (RT) cDNA synthesis}

Total RNA was extracted from cell lines using TRIzol ${ }^{\circledR}$ Reagent (Invitrogen). The concentration and purity of RNA was evaluated by spectrophotometry (Nanodrop Technologies, Inc). One $\mu \mathrm{g}$ of RNA was used for cDNA synthesis, using the High-Capacity cDNA Reverse Transcription Kit (Applied Biosystems), as recommended by the manufacturer.

\section{Quantitative polymerase chain reaction (qPCR)}

qPCR was performed in a CFX96 detection system (BioRad), using SSOfast Evagreen supermix (BioRad) following the manufacturer's instructions. Optimized cycling conditions for qPCR was as follows: enzyme activation for 30 seconds at $95^{\circ} \mathrm{C} ; 45$ cycles of denaturation at $95^{\circ} \mathrm{C}$ for 5 seconds and annealing/extension at $59^{\circ} \mathrm{C}$ for 5 seconds. Melting curve was assessed at $65^{\circ} \mathrm{C}-95^{\circ} \mathrm{C}$ (in $0.5^{\circ} \mathrm{C}$ increase) at each 5 seconds/step. The primers used are presented in Supplementary Table 1. The expression levels were normalized to $\beta$-actin by $\Delta \mathrm{CT}$ (relative expression) or by $\Delta \Delta \mathrm{CT}$ method (fold-change). Results are presented as the mean $\pm \mathrm{SD}$ of 3 independent experiences in triplicate.

\section{T- Box binding sites and primer design}

A total of $6 \mathrm{Kbs}(-5 \mathrm{~KB}$ to $+1 \mathrm{~Kb})$ for $C D 44$, Snail, Fibronectin, $N$-cadherin, $A M A C R$ and $A R$ were screened for T-Box binding consensus sequences (Supplementary Figure S3A). $\beta$-actin was used as negative control of Brachyury binding (data from ChIP-sequencing in human chordoma cells) [42]. To look for T-Box binding sites we used JASPAR database (http://jaspar.genereg.net) that contains a matrix-based nucleotide profile of binding preference for transcription factors from multiple species. Primers (Supplementary Table 1) were designed flanking regions enriched in T-Box binding sites.

\section{Chromatin immunoprecipitation (ChIP) - qPCR}

ChIP-qPCR analysis was performed in PC3 cell line containing Brachyury endogenous expression. The protocol used was adapted from [42]. Briefly, adherent PC3 cells $\left(\sim 3 \times 10^{7}\right)$ were fixed for 5 minutes in situ with $1.27 \%$ formaldehyde solution (Sigma F 8775 ). Immediate quenching of formaldehyde with glycine $2.5 \mathrm{M}$ (1/20 of total volume) was performed for 5 minutes. Cells were washed twice with $1 \times$ Dulbecco's phosphate buffered saline (PBS 1X), harvested using a cell scraper (Sarstedt, NC, USA), centrifuged and the pellet cells were quickly washed with ice-cold PBS 1X. PBS was totally removed 
and pellets were snap-frozen in liquid nitrogen and stored at $-80^{\circ} \mathrm{C}$.

Pellets were homogenized with cell lysis buffer (10mM Tris- $\mathrm{HCl} \mathrm{pH}=7.5,10 \mathrm{mM} \mathrm{NaCl}, 0.5 \% \mathrm{NP}-40)$ and left on ice for 1-2 hours. After centrifugation, supernatant pellet was re-suspended in nuclei lysis buffer $(50 \mathrm{mM}$ Tris- $\mathrm{HCl} \mathrm{pH}=7.5,10 \mathrm{mM}$ EDTA $\mathrm{pH}=8.0,1 \% \mathrm{SDS}$ ) and kept on ice for 15-30 minutes. At this stage, $2 \mathrm{X}$ volumes of IP dilution buffer $(16.7 \mathrm{mM}$ Tris- $\mathrm{HCl} \mathrm{pH}=7.5,167 \mathrm{mM}$ $\mathrm{NaCl}, 1.2 \mathrm{mM}$ EDTA $\mathrm{pH}=8.0,0.01 \%$ SDS) was added to each pellet of cells. Chromatin was solubilized and sheared to fragments of 100-500bp peaking around 200bp (Supplementary Figure S3B) using an ultrasonic processor (Vibra-cell sonicator; Sonics and Materials, INC) (10 cycles of 30 seconds shock waves at 3 Watt interrupted by 30 seconds pauses).

Magnetic Dynabeads Protein G (Novex, Life Technologies) were blocked in PBS containing $0.5 \%(\mathrm{w} / \mathrm{v})$ BSA and coupled to ChIP-grade antibody (or control rabbit $\mathrm{IgG}$ ) at $4^{\circ} \mathrm{C}$ overnight. $6 \mu \mathrm{g}$ of Brachyury antibody (sc20109, Santa Cruz Biotechnology) was coupled to $50 \mu \mathrm{l}$ of the appropriate Dynabeads Protein G. The soluble nuclear extract was prepared for immunoprecipitation by adding $80 \mu \mathrm{l}$ of $10 \%$ Triton X-100 per $1 \mathrm{ml}$ of chromatin. A sample of $50 \mu \mathrm{l}$ of ChIP input was collected at this stage and stored at $4^{\circ} \mathrm{C}$. Then the nuclear extract was combined with antibody-coupled beads (Brachyury or control $\mathrm{IgG}$ ) and incubated at $4^{\circ} \mathrm{C}$ overnight with rotation. After incubation, magnetic beads were precipitated using an eppendorfmagnet and washed with pre-chilled RIPA buffer $(50 \mathrm{mM}$ HEPES pH=7.6, 500mM LiCl, 1mM EDTA, 1\% NP-40, $0.7 \%(\mathrm{w} / \mathrm{v}) \mathrm{Na}$-deoxycholate). Bound chromatin was eluted from the beads with elution buffer $(50 \mathrm{mM}$ Tris- $\mathrm{HCl}$ $\mathrm{pH}=8.0,10 \mathrm{mM}$ EDTA $\mathrm{pH}=8.0,1 \% \mathrm{SDS}$ ) and reversed cross-linked in a thermomixer $\left(65^{\circ} \mathrm{C}, 6\right.$-hours $)$. After reverse cross-link, 1 volume of $\mathrm{TE} \mathrm{pH}=8.0$ and $200 \mu \mathrm{g}$ / $\mathrm{ml}$ of RNase A (Invitrogen) was added to the samples for a 1 -hour incubation at $37^{\circ} \mathrm{C}$. The samples were further treated with $200 \mu \mathrm{g} / \mathrm{ml}$ of proteinase K (Ambion) for 1 -hour at $55^{\circ} \mathrm{C}$. Finally, the DNA fragments were purified with phenol:chloroform:isoamylalcohol (phenol:Chl:1A, Sigma) and precipitated in $1 / 20$ volume of $5 \mathrm{M} \mathrm{NaCl}, 20 \mu \mathrm{g}$ of glycogen and ethanol. ChIP-chromatin was diluted in $30 \mu$ l of DNase-free water.

DNA enrichment was quantified in real-time PCR relative to locus-specific standard curves using CFX96TM system (BioRad). The percentage of DNA enrichment for a specific antibody was normalized to the amount of total DNA (equivalent to Input DNA): (Ab-IgG)/ Input. Real-time PCR was carried out with the following conditions: 30 seconds at $95^{\circ} \mathrm{C}, 5$ seconds at $59^{\circ} \mathrm{C}$ and $72^{\circ} \mathrm{C}$ respectively, 60 cycles. qPCR runs were performed with 3 technical replicates.

\section{Prostate-sphere assay}

Prostate sphere assay (adapted from [43]) was used to evaluate the capacity of prostate cells to grow and form spheres in suspension, an indicative of higher stemness phenotype. Each sample of cells was counted $\left(1 \times 10^{3}\right.$ cells/well), resuspended in $2 \mathrm{~mL}$ of Neurobasal media (Invitrogen, Carlsbad, CA), supplemented with $2 \mathrm{mM}$ glutamine and B27 (Invitrogen) and plated on a 12-well plate. Spheres were counted 3-15 days after plating. For passaging of spheres, media was collected centrifuged at $900 \mathrm{rpm}$ for 5 minutes to pellet the spheres. The supernatant was then removed and spheres were mechanically dissociated in $1 \mathrm{~mL}$ of fresh medium to obtain single cell suspension. Cells were counted and re-plated at a density of $1 \times 10^{3}$ cells/well to evaluate the capacity of self-renewal.

\section{Drug treatment and determination of half- maximal inhibitory concentration $\left(\mathrm{IC}_{50}\right)$}

The conventional and metastatic-second line PCa cytotoxic drugs docetaxel and cabazitaxel (MedChemTronica), respectively, were used to study the therapeutic value of Brachyury on PCa cells. Drugs were diluted in dimethyl sulfoxide (DMSO), as recommended by the manufacture. To determine the $\mathrm{IC}_{50}$ of the drugs $4 \times 10^{3}$ cells/well for $22 \mathrm{RV} 1$ and $2 \times 10^{3}$ cells/well for PC3 were plated into 96-well plates in triplicate and allowed to adhere overnight. After 6-hours of starvation (RPMI only) cells were treated with different concentrations of docetaxel $(0,0.5,2,5,10,100$ and $1000 \mathrm{nM})$ or cabazitaxel $(0,0.1,0.5,5,10,500$ and $1000 \mathrm{nM})$ in culture medium supplemented with 10\% FBS. After 48-hours of drug incubation the cellular viability was assessed by MTS (Promega, USA) in a 10:1 ratio and incubated in a humidified atmosphere at $37^{\circ} \mathrm{C}$ and $5 \% \mathrm{CO}_{2}$. Following 2 hours of incubation the optical density was determined at $490 \mathrm{~nm}$ in the Varioscan-Flash plate reader (Thermo Scientific). The cells treated with vehicle were incubated with culture medium containing 10\% FBS and 1\% DMSO. To assess AR and Brachyury protein expression after drug treatment cells were cultured $\left(3 \times 10^{5}\right.$ cells/well) in a 6 -well plate and allowed to adhere over-night. In the next day cells were treated with docetaxel or cabazitaxel (lowest $\mathrm{IC}_{50}$ for each cell line was used) for 24 hours. Controls were treated with $1 \%$ DMSO. Cells were then collected for protein extraction and western blot analyses.

\section{In silico microarray expression analysis}

Analysis of co-expression of Brachyury, AR, PTEN, $E R G, B c l-2$ and genes involved in NEtD (SYP and CHGA) was performed using data extracted from Oncomine 
database [44, 45]. For this study we used the Grasso dataset [46] compromising 28 normal prostate glands and $94 \mathrm{PCa}$ tissues, the only dataset with the information for the 7 genes of interest.

\section{Statistical analysis}

Correlations between Brachyury and AR expression in human samples were performed using the chi-square test $(\chi 2$-test). Simple comparisons between two different conditions were analyzed using Student's t test. The statistical analysis was performed using SPSS software (version 19.0) or using Prism GraphPad software (version 5.0a). The level of significance in the statistical analyses is indicated as $*=\mathrm{p}<0.05, * *=\mathrm{p}<0.01$ or $* * *=\mathrm{p}<0.001$.

\section{ACKNOWLEDGMENTS AND FUNDING}

This study was partially supported by the ICVS, and Molecular Oncology Research Center internal research founds and by UID/BIM/04773/2013 CBMR 1334. F. Pinto received fellowship from FCT ref SFRH/ BD/81369/2011. R.M. Reis has a National Counsel of Technological and Scientific Development (CNPq) scholarship.

\section{CONFLICTS OF INTERESTS}

There is no conflict of interest.

\section{REFERENCES}

1. Siegel R, Ma J, Zou Z, Jemal A. Cancer statistics, 2014. CA Cancer J Clin. 2014; 64: 9-29.

2. van Dodewaard-de Jong JM, Verheul HM, Bloemendal HJ, de Klerk JM, Carducci MA, van den Eertwegh AJ. New Treatment Options for Patients With Metastatic Prostate Cancer: What Is The Optimal Sequence? Clin Genitourin Cancer. 2015; pii: S1558-7673(15)00010-5.

3. Moul JW, Evans CP, Gomella LG, Roach M, Dreicer R. Traditional approaches to androgen deprivation therapy. Urology. 2011; 78: S485-93.

4. Tannock IF, de Wit R, Berry WR, Horti J, Pluzanska A, Chi KN, Oudard S, Théodore C, James ND, Turesson I, Rosenthal MA, Eisenberger MA; TAX 327 Investigators. Docetaxel plus prednisone or mitoxantrone plus prednisone for advanced prostate cancer. NEJM. 2004; 351: 1502-12.

5. Berthold DR, Pond GR, Soban F, de Wit R, Eisenberger M, Tannock IF. Docetaxel plus prednisone or mitoxantrone plus prednisone for advanced prostate cancer: updated survival in the TAX 327 study. J Clin Oncol. 2008; 26: 2425.

6. Sweeney CJ, Chen YH, Carducci M, Liu G, Jarrard DF, Eisenberger M, Wong YN, Hahn N, Kohli M, Cooney
MM, Dreicer R, Vogelzang NJ, Picus J. Chemohormonal Therapy in Metastatic Hormone-Sensitive Prostate Cancer. NEJM. 2015; 373: 737-46.

7. Scher HI, Fizazi K, Saad F, Taplin ME, Sternberg CN, Miller K, de Wit R, Mulders P, Chi KN, Shore ND, Armstrong AJ, Flaig TW, Fléchon A, Mainwaring P, Fleming M, Hainsworth JD, et al. Increased survival with enzalutamide in prostate cancer after chemotherapy. NEJM. 2012; 367: 1187-97.

8. de Bono JS, Logothetis CJ, Molina A, Fizazi K, North S, Chu L, Chi KN, Jones RJ, Goodman OB Jr, Saad F, Staffurth JN, Mainwaring P, Harland S, Flaig TW, Hutson TE, Cheng T, et al. Abiraterone and increased survival in metastatic prostate cancer. NEJM. 2011; 364: 1995-2005.

9. de Bono JS, Oudard S, Ozguroglu M, Hansen S, Machiels JP, Kocak I, Gravis G, Bodrogi I, Mackenzie MJ, Shen L, Roessner M, Gupta S, Sartor AO; TROPIC Investigators. Prednisone plus cabazitaxel or mitoxantrone for metastatic castration-resistant prostate cancer progressing after docetaxel treatment: a randomised open-label trial. Lancet. 2010; 376: 1147-54.

10. Oudard S. TROPIC: Phase III trial of cabazitaxel for the treatment of metastatic castration-resistant prostate cancer. Future Oncol. 2011 7:497-506.

11. Lamont KR, Tindall DJ. Minireview: Alternative activation pathways for the androgen receptor in prostate cancer. Mol Endocrinol. 2011; 25: 897-907

12. Nouri M, Ratther E, Stylianou N, Nelson CC, Hollier BG, Williams ED. Androgen-targeted therapy-induced epithelial mesenchymal plasticity and neuroendocrine transdifferentiation in prostate cancer: an opportunity for intervention. Front Oncol. 2014; 4: 370.

13. Sun Y, Wang BE, Leong KG, Yue P, Li L, Jhunjhunwala S, Chen D, Seo K, Modrusan Z, Gao WQ, Settleman J, Johnson L. Androgen deprivation causes epithelialmesenchymal transition in the prostate: implications for androgen-deprivation therapy. Cancer Res. 2012; 72: 527 36.

14. Tang DG, Patrawala L, Calhoun T, Bhatia B, Choy G, Schneider-Broussard R, Jeter C. Prostate cancer stem/ progenitor cells: Identification, characterization, and implications. Mol Carcinog. 2007; 46: 1-14.

15. Xiao W, Graham PH, Power CA, Hao J, Kearsley JH, Li Y. CD44 is a biomarker associated with human prostate cancer radiation sensitivity. Clin Exp Metastasis. 2012; 29: 1-9.

16. Yang JC, Ok JH, Busby JE, Borowsky AD, Kung HJ, Evans CP. Aberrant activation of androgen receptor in a new neuropeptide-autocrine model of androgen-insensitive prostate cancer. Cancer Res. 2009; 69: 151-60.

17. Imajyo I, Sugiura T, Kobayashi Y, Shimoda M, Ishii K, Akimoto N, Yoshihama N, Kobayashi I, Mori Y. T-box transcription factor Brachyury expression is correlated with epithelial-mesenchymal transition and lymph node metastasis in oral squamous cell carcinoma. Int J Oncol. 
2012; 41: 1985-95.

18. Roselli M, Fernando RI, Guadagni F, Spila A, Alessandroni J, Palmirotta R, Costarelli L, Litzinger M, Hamilton D, Huang B, Tucker J, Tsang KY, Schlom J, Palena C. Brachyury, a driver of the epithelial-mesenchymal transition, is overexpressed in human lung tumors: an opportunity for novel interventions against lung cancer. Clin Cancer Res. 2012; 18: 3868-79.

19. Fernando RI, Litzinger M, Trono P, Hamilton DH, Schlom J, Palena C. The T-box transcription factor Brachyury promotes epithelial-mesenchymal transition in human tumor cells. J Clin Invest. 2010; 120: 533-44.

20. Pinto F, Campanella NC, Abrahão-Machado LF, Scapulatempo-Neto C, de Oliveira AT, Brito MJ, Andrade RP, Guimarães DP, Reis RM. The embryonic Brachyury transcription factor is a novel biomarker of GIST aggressiveness and poor survival. Gastric Cancer. 2016; 19: 651-659. doi: 10.1007/s10120-015-0505-0.

21. Pinto F, Pertega-Gomes N, Pereira MS, Vizcaino JR, Monteiro P, Henrique RM, Baltazar F, Andrade RP, Reis RM. T-box transcription factor Brachyury is associated with prostate cancer progression and aggressiveness. Clin Cancer Res. 2014; 20: 4949-61.

22. Hotta K, Takahashi H, Satoh N, Gojobori T. Brachyurydownstream gene sets in a chordate, Ciona intestinalis: integrating notochord specification, morphogenesis and chordate evolution. Evol Dev. 2008; 10: 37-51.

23. Fernando RI, Castillo MD, Litzinger M, Hamilton DH, Palena C. IL-8 signaling plays a critical role in the epithelial-mesenchymal transition of human carcinoma cells. Cancer Res. 2011; 71: 5296-306.

24. Imajyo I, Sugiura T, Kobayashi Y, Shimoda M, Ishii K, Akimoto N, Yoshihama N, Kobayashi I, Mori Y. T-box transcription factor Brachyury expression is correlated with epithelial-mesenchymal transition and lymph node metastasis in oral squamous cell carcinoma. Int J Oncol. 2012; 41: 1985-95.

25. Shimoda M, Sugiura T, Imajyo I, Ishii K, Chigita S, Seki K, Kobayashi Y, Shirasuna K. The Tbox transcription factor Brachyury regulates epithelial-mesenchymal transition in association with cancer stem-like cells in adenoid cystic carcinoma cells. BMC Cancer. 2012; 12: 377.

26. Jezkova J, Williams JS, Jones-Hutchins F, Sammut SJ, Gollins S, Cree I, Coupland S, McFarlane RJ, Wakeman JA. Brachyury regulates proliferation of cancer cells via a p27Kip1-dependent pathway. Oncotarget. 2014; 5: 381322. doi: 10.18632/oncotarget.1999.

27. Palena C, Roselli M, Litzinger MT, Ferroni P, Costarelli L, Spila A, Cavaliere F, Huang B, Fernando RI, Hamilton DH, Jochems C, Tsang KY, Cheng Q, Lyerly HK, Schlom J, Guadagni F. Overexpression of the EMT driver brachyury in breast carcinomas: association with poor prognosis. J Natl Cancer Inst. 2014; 106. pii: dju054.

28. Huang B, Cohen JR, Fernando RI, Hamilton DH, Litzinger
MT, Hodge JW, Palena C. The embryonic transcription factor Brachyury blocks cell cycle progression and mediates tumor resistance to conventional antitumor therapies. Cell Death Dis. 2013; 4: e682.

29. Sarkar D, Shields B, Davies ML, Müller J, Wakeman JA. BRACHYURY confers cancer stem cell characteristics on colorectal cancer cells. Int J Cancer. 2012; 130:328-37.

30. Thomas C. Prostate cancer: Brachyury--a biomarker for progression and prognosis? Nat Rev Urol. 2014; 11: 485.

31. Yoshimoto M, Cunha IW, Coudry RA, Fonseca FP, Torres $\mathrm{CH}$, Soares FA, Squire JA FISH analysis of 107 prostate cancers shows that PTEN genomic deletion is associated with poor clinical outcome. Br J Cancer. 2007; 97: 678-685.

32. Trotman LC, Niki M, Dotan ZA, Koutcher JA, Di Cristofano A, Xiao A, Khoo AS, Roy-Burman P, Greenberg NM, Van Dyke T, Cordon-Cardo C, Pandolfi PP. Pten dose dictates cancer progression in the prostate. PLoS Biol. 2003; 1: E59.

33. Jezkova J, William JS, Pinto F, Sammut SJ, Wiliams GT, Gollins S, McFarlane RJ, Reis RM, Wakeman JA. Brachyury identifies a class of enteroendocrine cells in normal human intestinal crypts and colorectal cancer. Oncotarget. 2016; 7: 11478-11486. doi: 10.18632/ oncotarget.7202.

34. Perets R, Kaplan T, Stein I, Hidas G, Tayeb S, Avraham E, Ben-Neriah Y, Simon I, Pikarsky E. Genome-wide analysis of androgen receptor targets reveals COUP-TF1 as a novel player in human prostate cancer. PLoS One. 2012; 7: e46467.

35. Huang H, Cheville JC, Pan Y, Roche PC, Schmidt LJ, Tindall DJ. PTEN induces chemosensitivity in PTENmutated prostate cancer cells by suppression of Bcl-2 expression. J Biol Chem. 2001; 276:38830-38836.

36. Fallahabadi ZR, Noori Daloii MR, Mahdian R, Behjati F, Shokrgozar MA, Abolhasani M, Asgari M, Shahrokh H. Frequency of PTEN alterations, TMPRSS2-ERG fusion and their association in prostate cancer. Gene. 2016; 575:755760.

37. Tamaki H, Harashima N, Hiraki M, Arichi N, Nishimura N, Shiina H, Naora K, Harada M. Bcl-2 family inhibition sensitizes human prostate cancer cells to docetaxel and promotes unexpected apoptosis under caspase-9 inhibition. Oncotarget. 2014; 5:11399-11412. doi: 10.18632/ oncotarget. 2550.

38. Squire JA. TMPRSS2-ERG and PTEN loss in prostate cancer. Nat Genet. 2009; 41:509-510.

39. Du R, Wu S, Lv X, Fang H, Wu S, Kang J. Overexpression of brachyury contributes to tumor metastasis by inducing epithelial-mesenchymal transition in hepatocellular carcinoma. J Exp Clin Cancer Res. 2014; 33:105.

40. Heery CR, Singh H, Marte JL, Madan RA, O'Sullivan Coyne GH, Farsaci, Rodell TC, Palena C, Scholm J, Gulley JL. NCI experience using yeast-brachyry vaccine (GI-6301) in patients with advanced chordoma. J Clinical Oncol. 
2014; 32, Suppl. abstr 3081.

41. Shing H, Heery CR, Marte JL, Farsaci B, Madan RA, O’Sullivan Coyne GH, Farsaci, Rodell TC, Palena C, Scholm J, Gulley JL. A phase I study of a yeast-based therapeutic cancer vaccine, GI-6301, targeting brachyury in patients with metastatic carcinoma. J Clinical Oncol. 2014; 32, Suppl. abctr e14026.

42. Nelson AC, Pillay N, Henderson S, Presneau N, Tirabosco R, Halai D, Berisha F, Flicek P, Stemple DL, Stern CD, Wardle FC, Flanagan AM. An integrated functional genomics approach identifies the regulatory network directed by brachyury (T) in chordoma. J Pathol. 2012; 228: 274-85.

43. Lang SH, Anderson E, Fordham R, Collins AT. Modeling the Prostate Stem Cell Niche: An Evaluation of Stem Cell Survival and Expansion In Vitro. Stem Cells Dev. 2010; 19:
537-546.

44. Oncomine. Ann Arbor, MI:Compendia Bioscience@ 20072010. Available from: https://www.oncomine.org.

45. Rhodes DR, Kalyana-Sundaram S, Mahavisno V, Varambally R, Yu J, Briggs BB, Barrette TR, Anstet MJ, Kincead-Beal C, Kulkarni P, Varambally S, Ghosh D, Chinnaiyan AM. Oncomine 3.0: Genes, pathways, and networks in a collection of 18,000 cancer gene expression profiles. Neoplasia. 2007; 9: 166-80.

46. Grasso CS, Wu YM, Robinson DR, Cao X, Dhanasekaran SM, Khan AP, Quist MJ, Jing X, Lonigro RJ, Brenner JC, Asangani IA, Ateeq B, Chun SY, Siddiqui J, Sam L, Anstett $\mathrm{M}$, et al. The mutational landscape of lethal castrationresistant prostate cancer. Nature. 2012; 487: 239-43. 